\title{
INVESTIGATIONS OF THE OXYGEN-18 CONTENT OF SAMPLES FROM SNOW PITS AND ICE CORES FROM THE FILCHNER-RONNE ICE SHELVES AND EKSTRÖM ICE SHELF
}

\author{
by
}

\author{
O. Reinwarth and W. Graf,
}

(Kommission für Glaziologie der Bayerischen Akademie der Wissenschaften, Matstallplatz 8, D-8000 München 22, West Germany)

and W. Stichler, H. Moser and H. Oerter

(GSF-Institut für Radiohydrometrie, D-8042 Neuherberg, Oberschleissheim, West Germany)

\begin{abstract}
Since 1979-80, isotope studies with oxygen-18 $\left({ }^{18} \mathrm{O}\right)$ have been carried out at several snow pits and ice cores near the German Georg-von-Neumayer station (Ekström ice shelf, Atka Bay), as well as from the Filchner-Ronne ice shelves, in the framework of the German Antarctic research programme. The investigations of snow pits on the Filchner-Ronne ice shelves yield a standard deviation for the annual average $\delta^{18} \mathrm{O}$ values of approximately $1 \%$ over the last five years, and a decrease of $\delta^{18} \mathrm{O}$ with distance from the ice edge of about $1 \%$ per 50 $\mathrm{km}$. The variation of $\delta^{18} \mathrm{O}$ for stratigraphically matching snow layers from snow pits at the same location in different years is about $0.3 \%$ on the Filchner-Ronne ice shelves, and $0.8 \%$ at Georg-von-Neumayer station. The mean annual accumulation rate in the surroundings of Georg-von-Neumayer station was determined to be 34 $\mathrm{g} \mathrm{cm}^{-2}$ for the years 1977-81. On the Filchner-Ronne ice shelves the mean annual accumulation rate (1979-83) decreases from $22 \mathrm{~g} \mathrm{~cm}^{-2}$ at Filchner station to $15 \mathrm{~g}$ $\mathrm{cm}^{-2}$ at traverse point T340, located $200 \mathrm{~km}$ southeast of Filchner station.
\end{abstract}

\section{INTRODUCTION}

Since the 1979-80 season, when the German pre-site survey expedition was carried out (Reinwarth 1981), annual expeditions have taken place on the Ekström ice shelf (Atka Bay), where the permanent German Antarctic research station Georg-von-Neumayer was established in 1980, and to the Filchner-Ronne ice shelves (starting from the Filchner station, the German summer base camp). In Figure 1 these two locations are indicated, marking the area under investigation.

The glaciological part of the German Antarctic research programme comprises (a) the determination of the annual accumulation rates (which are indispensable for all investigations concerning the mass balance of the two ice shelves), (b) investigations concerning the functional relation between the isotope contents $\left({ }^{18} \mathrm{O} /{ }^{16} \mathrm{O}\right.$, $\left.{ }^{2} \mathrm{H} /{ }^{1} \mathrm{H},{ }^{3} \mathrm{H} /{ }^{1} \mathrm{H}\right)$ in accumulated snow and ice and the climatic environment. First evaluations of accumulation rates by means of
${ }^{2} \mathrm{H},{ }^{18} \mathrm{O}$ and ${ }^{3} \mathrm{H}$ levels of snow and ice samples from both sites were published by Reinwarth and others (1982). The following contribution is a progress report on results of further isotope investigations within the framework of German Antarctic activities.

\section{SAMPLING}

In the years 1980-84 snow pits were dug between 2 and $6 \mathrm{~m}$ in depth near both stations. Two cores, 10.5 and $51.7 \mathrm{~m}$ in length, were drilled in 1980 and 1982 at Georg-von-Neumayer station. In 1984 the programme was extended by a traverse on the Filchner-Ronne ice shelves (Fig.2) leading from the Filchner station (T140) $250 \mathrm{~km}$ to the south-east. Snow pits were dug every

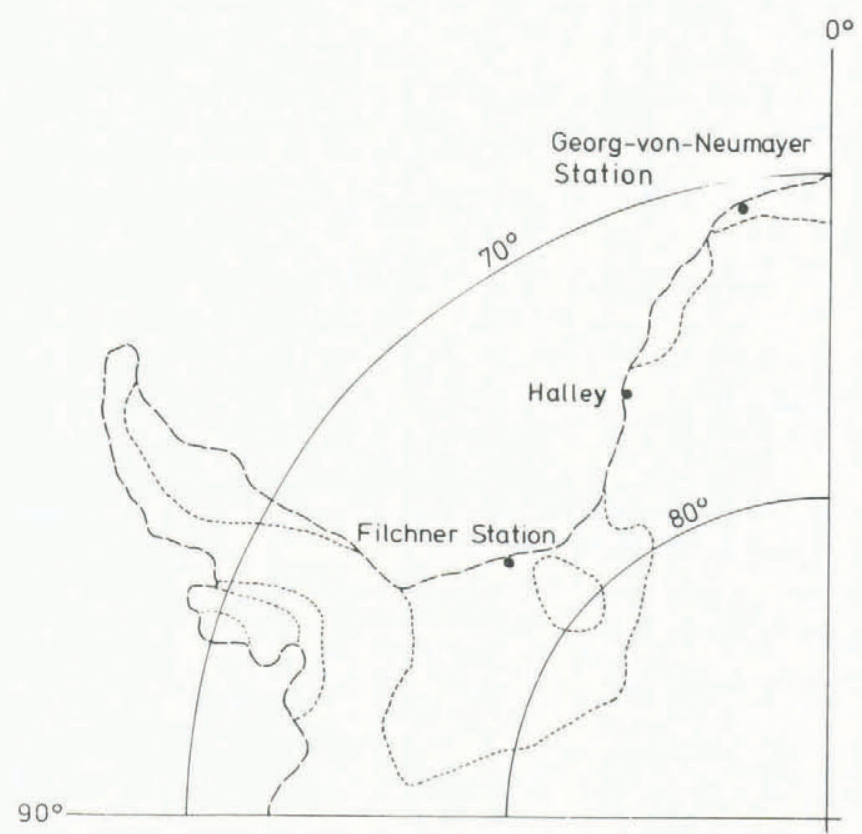

Fig.1. Weddell Sea sector of Antarctica.

$50 \mathrm{~km}$, and a bore hole to $100 \mathrm{~m}$ depth was carried out at traverse point $\mathrm{T} 340,200 \mathrm{~km}$ from Filchner station. Pits were also dug every $150 \mathrm{~km}$ along the ice edge, starting from the Filchner station and extending $450 \mathrm{~km}$ west.

The snow pits were stratigraphically analyzed, the density and temperature of the different snow layers determined, and samples taken for isotope analysis. The snow pit samples were melted and poured into bottles. The cores were cut into $1 \mathrm{~m}$ lengths, wrapped and transported frozen to the laboratory, where they were cut into equal pieces and melted.

At the sampling locations the firn temperature at $10 \mathrm{~m}$ depth was also measured. This temperature is representative of the mean annual near-surface air temperature, since no melting usually occurs at the surface of all the sites mentioned.

\section{RESULTS AND DISCUSSION}

The ${ }^{18} \mathrm{O}$ content of the snow pits and ice cores show the well-known seasonal variation, characterized by high ${ }^{18} \mathrm{O}$ content in summer snow layers and $10 w{ }^{18} \mathrm{O}$ content in winter layers. This can be seen in Figure 3, where the results for traverse point T340 are plotted. Techniques for dating ice cores and snow pits by means of ${ }^{18} \mathrm{O}$ content rely on this periodicity. The 


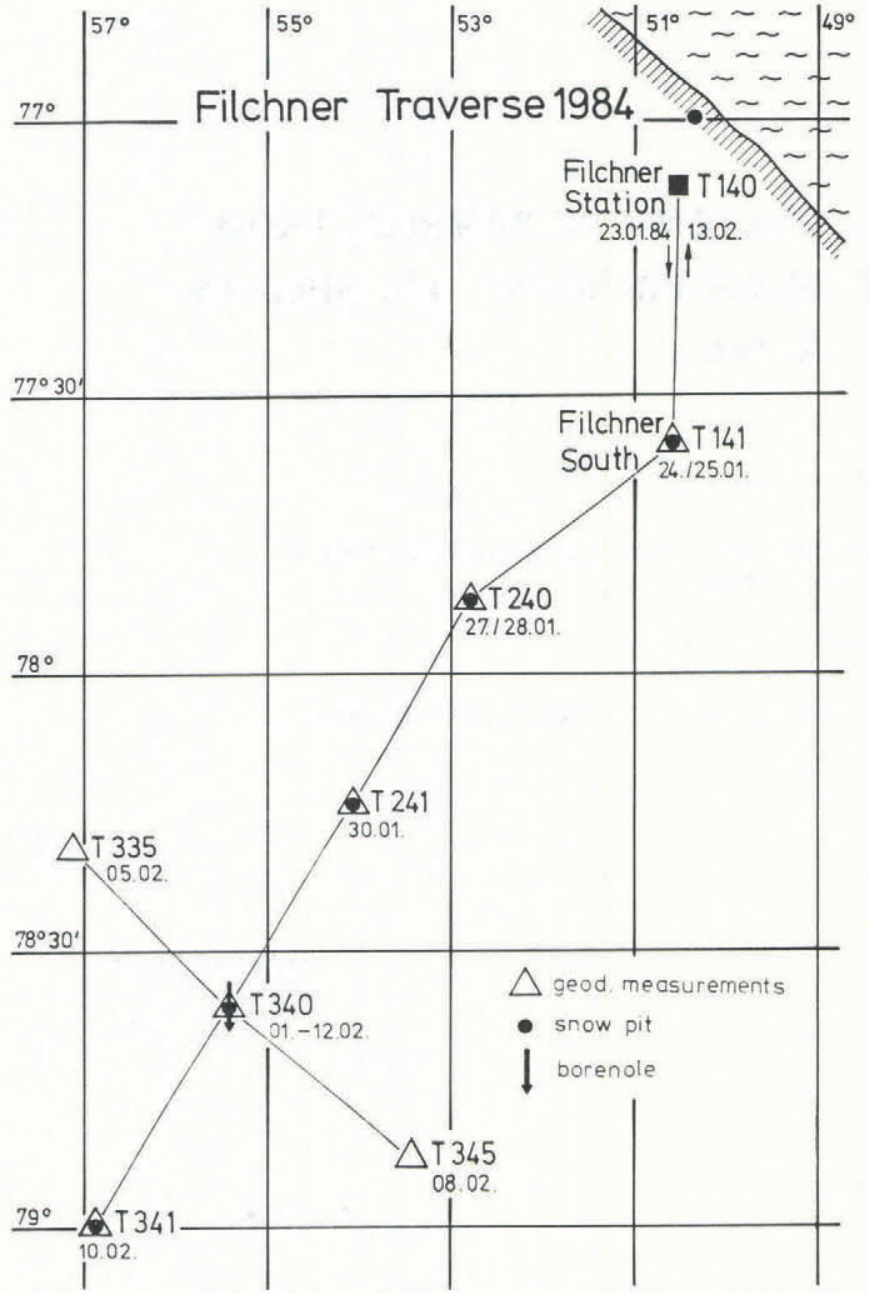

Fig2. Filchner traverse of the 1983-84 expedition into the Filchner-Ronne ice shelves.

\section{Snow Profile Point T 340}

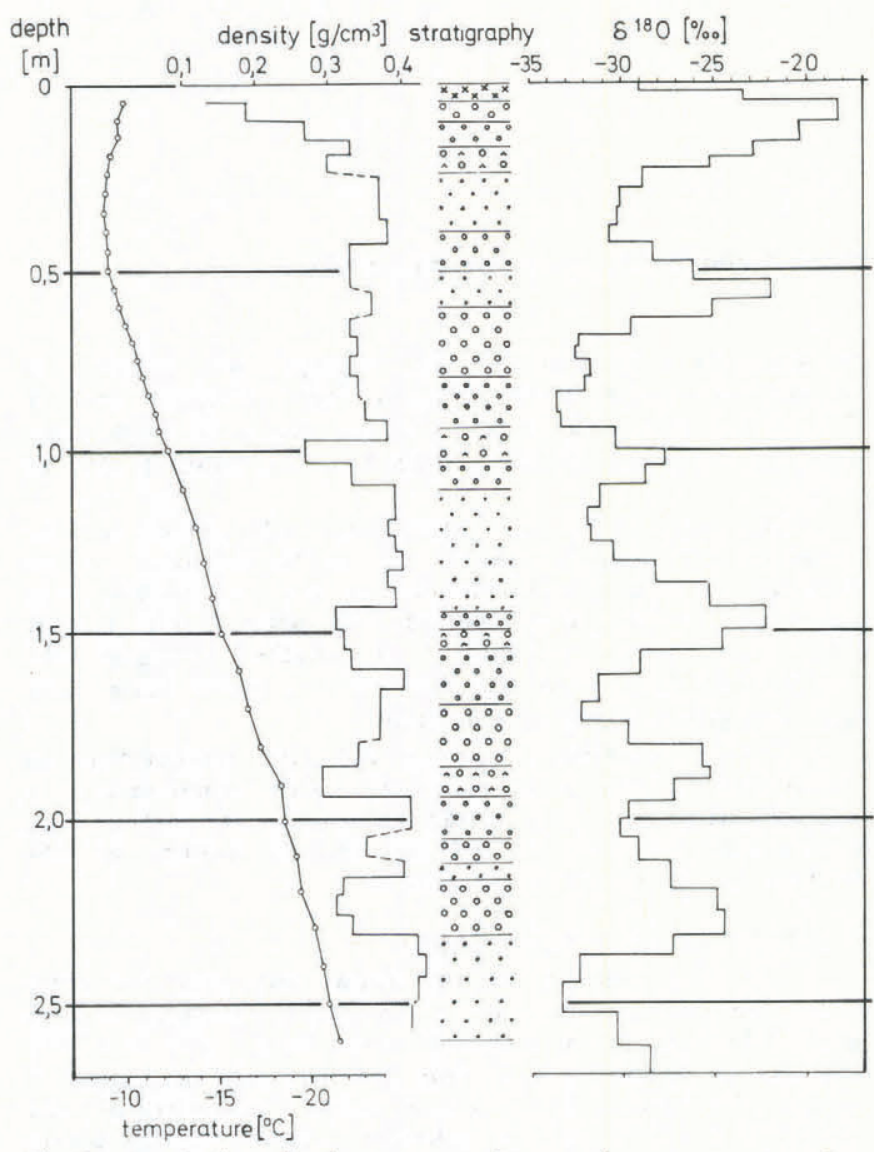

Fig.3. Analysis of the snow pit at the traverse point T340 (Fig.2), February 1984. stratigraphical profile also shows a similar quasiperiodic layering with coarse, low-density, partly metamorphosed summer material, and fine-grained winter material. The beginning of the winter is marked by the boundary between the highly transparent summer accumulation and the overlaying opaque winter material.

As seen in Figure 3 the determination of the annual layering by means of the isotope content can be much more accurate than that by stratigraphy, especially if the accumulation rate or the rate of metamorphism is low.

\subsection{Accumulation rate}

Mean annual accumulation rates were deduced from the isotopic results in combination with the stratigraphy of the snow pits. The results are given in Table I. The amount of precipitation is correlated with the water vapour pressure (Robin 1977, Robin and Johnsen 1983). In Figure 4, the measured accumulation rates and the calculated vapour pressure over the ice are plotted as

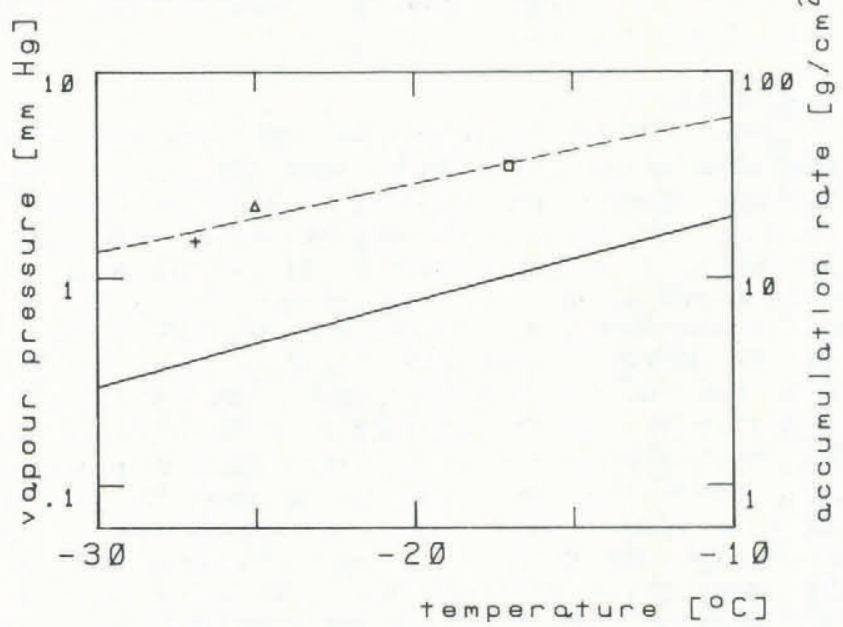

Fig.4. Correlation between vapour pressure over ice and near-surface air temperature after Robin (1977) (full line), and accumulation rates at Filchner station $(\Delta)$, traverse point T340 (+), and Georg-von-Neumayer station (a) (Figs.1 and 2) as a function of the 10 m-depth firn temperature, which corresponds to the mean annual near-surface air temperature. The dashed line represents the regression line.

functions of temperature. The accumulation rate and the vapour pressure display a similar decrease with decreasing temperature.

\subsection{Fluctuations of the isotope conten}

The snow pits, which were dug in successive years, partly overlap corresponding annual layers. It is thus possible to compare the isotopic contents of the same annual layer at adjacent sites.

It is assumed that firn layers matched between pits contain the same isotopic record, however they may be different in thickness. Thus, when comparing two isotope profiles of snow pits and ice cores, the depth axis of one of them may be deformed so that the extremities of the two curves coincide. The resulting profiles are then superimposed.

Figure 5 shows the ${ }^{18} \mathrm{O}$ profiles of two snow pits dug in 1983 (right) and 1984 (left), near Filchner station. The deformed profile of 1983 is superimposed on the profile of 1984. The agreement between these profiles is apparent.

Figure 6 shows a similar example taken from Georg-von-Neumayer station. Here the ${ }^{18} \mathrm{O}$ profile of a snow pit dug in 1980 is compared with the corresponding part of the ice core drilled in 1982. The agreement between the isotopic contents is also very good.

In the last example (Fig.7), certain differences exist in the isotopic content of corresponding annual layers. Here the ${ }^{18} \mathrm{O}$ profile of a snow pit dug in 1981 near 
TABLE I. SNOW PIT AND ICE CORE INVESTIGATIONS AT EKSTRÖM ICE SHELF AND FILCHNER-RONNE ICE SHELVES

\begin{tabular}{|c|c|c|c|c|c|}
\hline Site & $\begin{array}{l}\text { Time of } \\
\text { investi- } \\
\text { gation }\end{array}$ & $\begin{array}{l}\text { Mean annual } \\
{ }^{18} \mathrm{O} \text { content } \\
(\%)\end{array}$ & $\begin{array}{c}\text { Range of an- } \\
\text { nual }{ }^{18} \mathrm{O} \text { con- } \\
\text { tent } \\
(\% \circ)\end{array}$ & $\begin{array}{l}\text { Mean annual } \\
\text { accumulation } \\
\text { rate* } \\
\left(\mathrm{g} \mathrm{cm}^{-2}\right)\end{array}$ & $\begin{array}{l}\text { Temperature } \\
\text { at } 10 \mathrm{~m} \\
\text { depth } \\
\left({ }^{\circ} \mathrm{C}\right)\end{array}$ \\
\hline $\begin{array}{l}\text { Georg-von-Neumayer } \\
\text { station }\end{array}$ & $1977-81$ & $-18.8 \pm 1.0$ & -20.6 to -18.1 & 34 & -17.0 \\
\hline Filchner station & $1979-83$ & $-24.3 \pm 0.8$ & -24.5 to -23.1 & 22 & -25.0 \\
\hline Traverse point $\mathrm{T} 340$ & $1979-83$ & $-28.3 \pm 1.5$ & -30.1 to -26.1 & 15 & -26.9 \\
\hline Halley station ** & $1976-81$ & $-20.9 \pm 1.6$ & -21.9 to -19.3 & N/A & -18.2 \\
\hline
\end{tabular}

* Calculated from extremes of ${ }^{18} \mathrm{O}$ content and stratigraphic results corresponding to the listed time periods.

** IAEA (1981, 1983).

\section{$\delta \quad 18-0 \quad[\%$,}

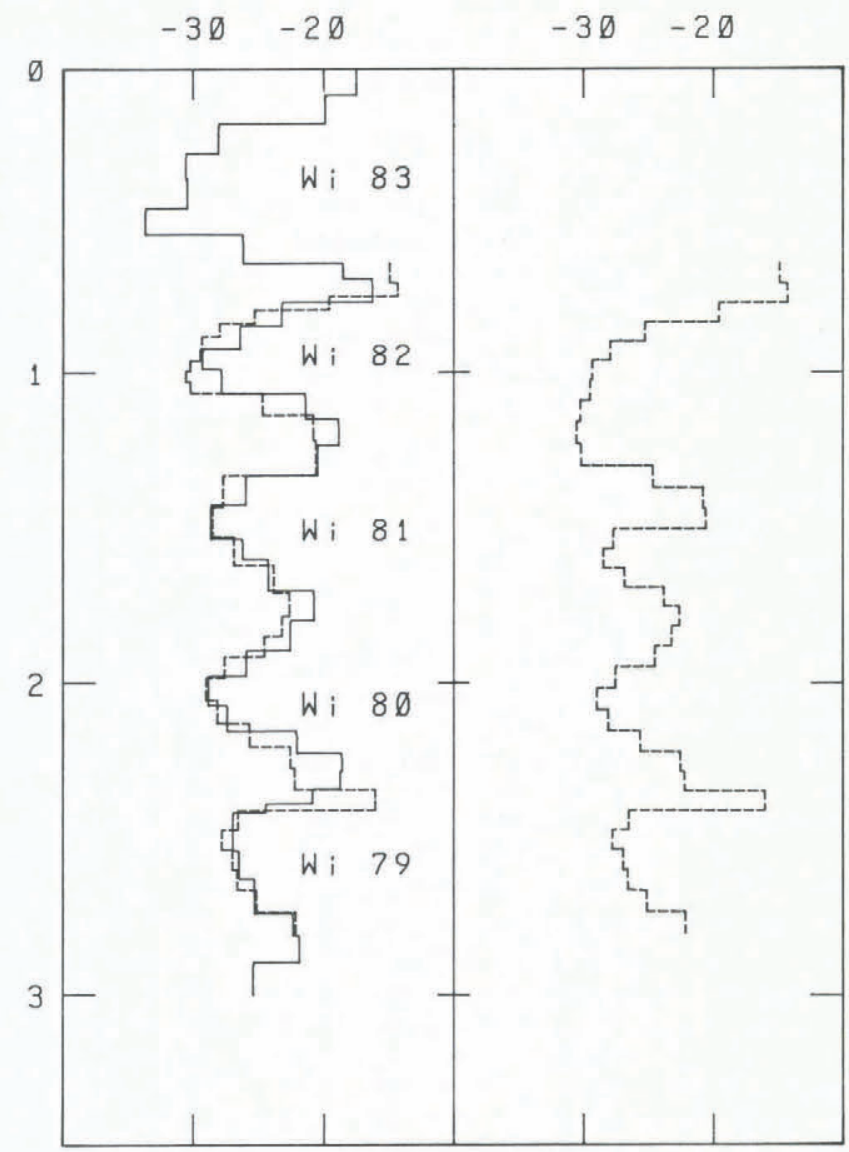

1984

depth $[m]$

Fig.5. Profiles of ${ }^{18} \mathrm{O}$ content in snow pits located near Filchner station (T140) dug in 1983 and 1984. The depth axis of the 1983 curve (right) has been deformed and the ${ }^{18} \mathrm{O}$ profile superimposed on the 1984 profile (left).
6 $18-0 \quad[\%$,

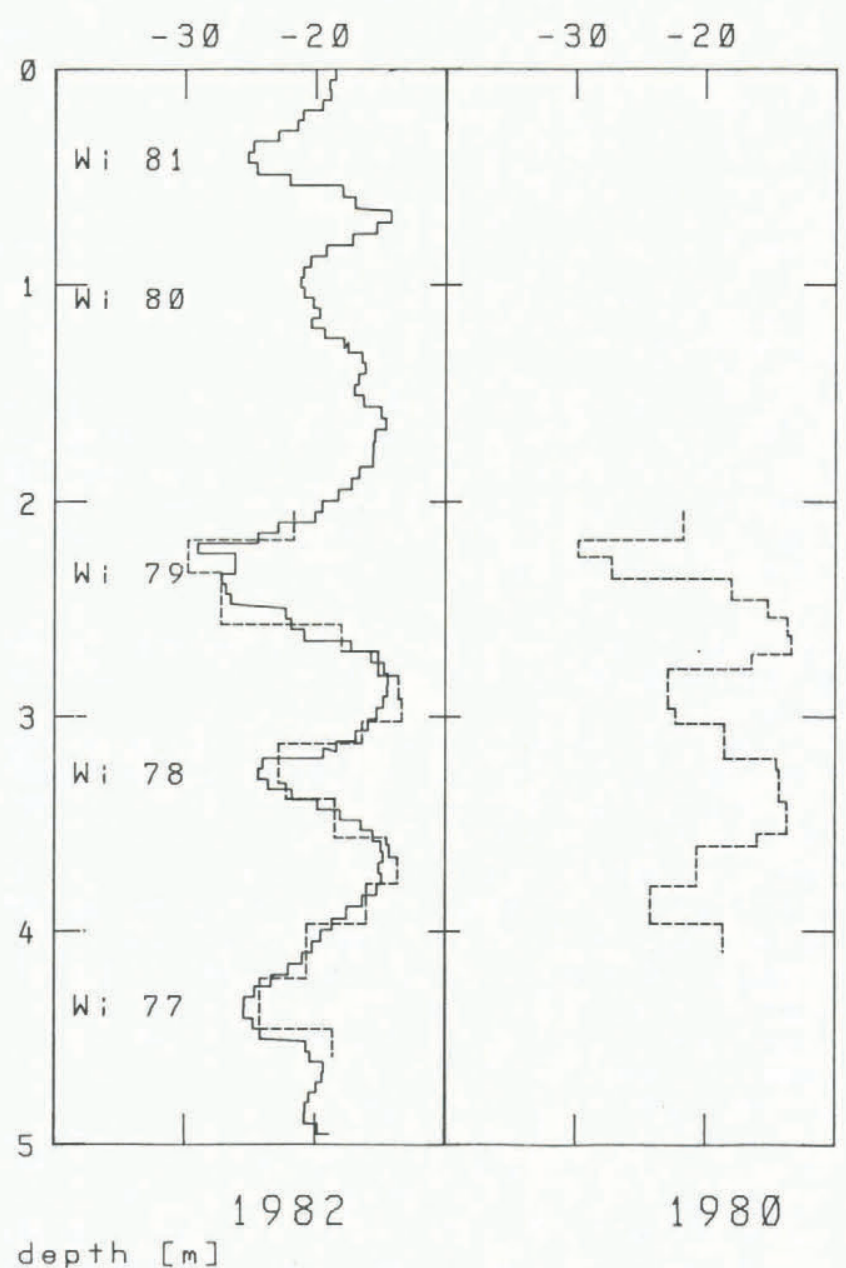

Fig.6. Profiles of ${ }^{18} \mathrm{O}$ content in a snow pit dug in 1980 , and in the topmost part of an ice core drilled in 1982, both located near Georg-von-Neumayer station. The depth axis of the 1980 curve (right) has been deformed and the ${ }^{18} \mathrm{O}$ profile superimposed on the 1982 profile (left) 


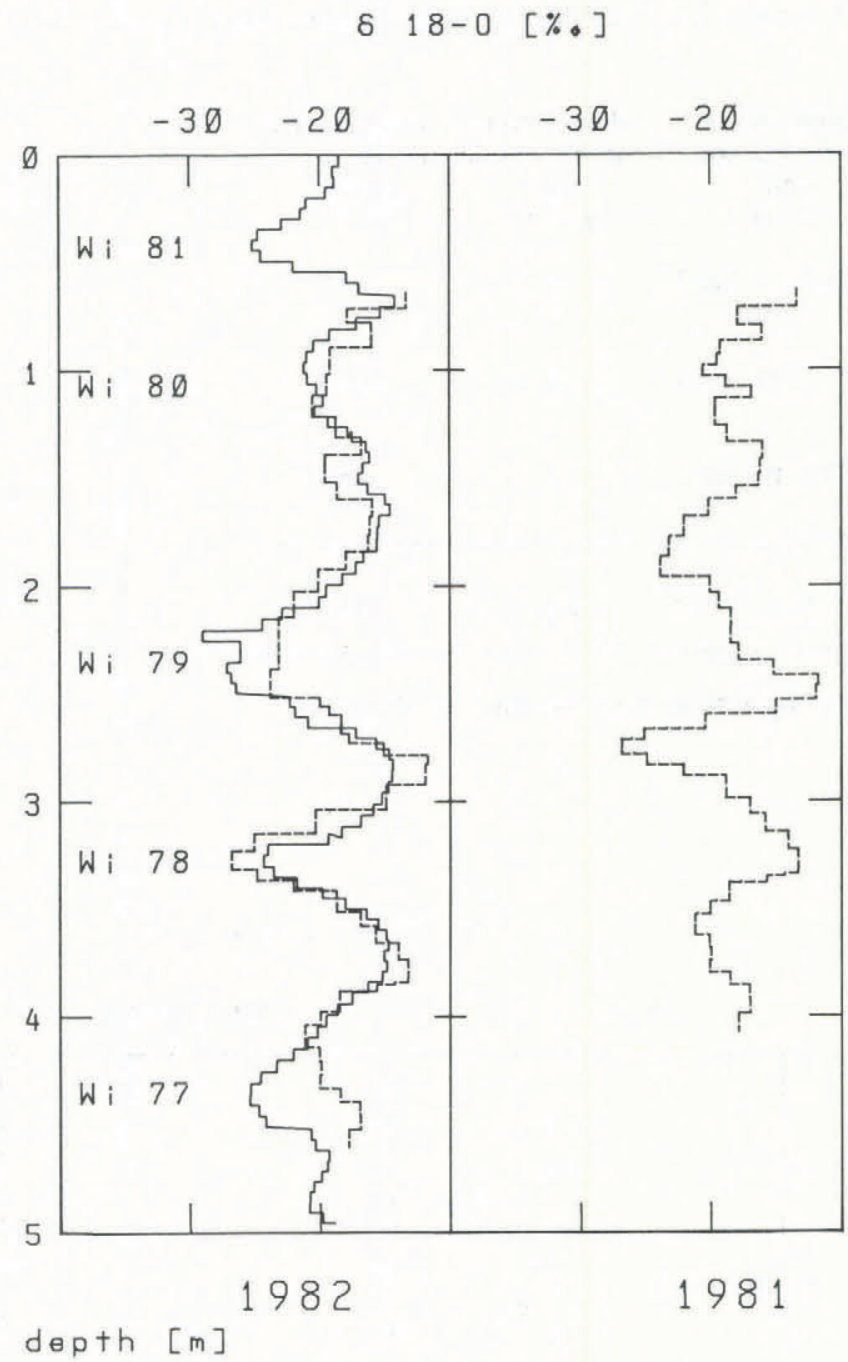

Fig.7. Profiles of ${ }^{18} \mathrm{O}$ content in a snow pit dug in 1981 , and of the topmost part of an ice core drilled in 1982, both located near Georg-von-Neumayer station. The depth axis of the 1981 curve (right) has been deformed and the ${ }^{18} \mathrm{O}$ profile superimposed on the 1982 profile (left).

Georg-von-Neumayer station is superimposed on the corresponding part of the same ice core in the last example.

The following conclusions may be drawn from these comparisons of ${ }^{18} \mathrm{O}$ profiles at different sites. The mean ${ }^{18} \mathrm{O}$ contents in corresponding annual layers at two adjacent sites differ by amounts of up to $0.7 \%$ at Filchner station, and of up to $1.8 \%$ at Georg-von-Neumayer station. The resulting mean standard deviation $(1 \sigma)$ is $0.3 \%$ at Filchner station, and $0.8 \%$ 。 at Georg-von-Neumayer station. These fluctuations in the isotopic record must be taken into account if temperature information is to be inferred from the mean annual ${ }^{18} \mathrm{O}$ content in snow and ice horizons.

3.3. Mean annual isotopic content

In Table I the mean annual ${ }^{18} \mathrm{O}$ contents during the observation period, and the variation ranges of this content, are compiled for different locations. As in the case of the accumulation rate there is a decrease of the ${ }^{18} \mathrm{O}$ content with decreasing mean near-surface air temperature, as seen in Figure 8. In addition the graph of the empirically established relation (Equation (1)) between ${ }^{18} \mathrm{O}$ content and the near-surface air temperature $\theta$ at different locations over East Antarctica (Lorius and Merlivat 1977, Lorius 1983) is plotted in Figure 8.

$$
\delta^{18} \mathrm{O}=0.755 \theta-7.6
$$

The year-to-year differences of the annual mean ${ }^{18} \mathrm{O}$ content (Table I) are generally greater than the

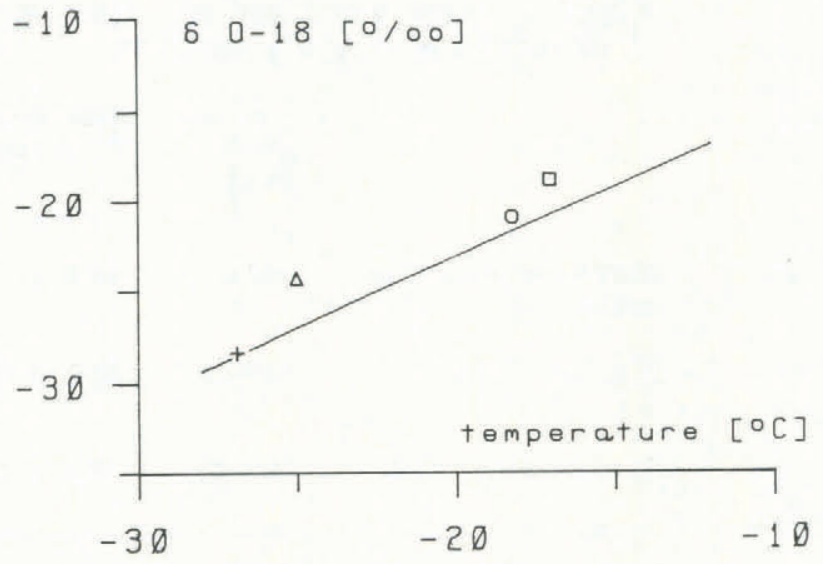

Fig. 8. Mean annual oxygen-18 contents at Georg-von-Neumayer station ( $\square)$, Filchner station $(\Delta)$, and traverse point $\mathrm{T} 340(+)$ plotted against the 10 m-depth firn temperature, which corresponds to the mean annual near-surface air temperature. For comparison the ${ }^{18} \mathrm{O}$ content at Halley station (o) is also shown as a function of air temperature (IAEA 1981, 1983) (cf. Table I). The full line corresponds to Equation (1) (Lorius and Merlivat 1977).

local fluctuations in the same annual layer (cf. section $3.2)$.

Unfortunately no near-surface air temperatures are available at Filchner station or Georg-von-Neumayer station to confirm whether the changes in the ${ }^{18} \mathrm{O}$ content of the annual layers may be correlated with annual temperature changes or not. For Halley station, where temperature and isotope data are available (IAEA $1981,1983)$, no correlation between the weighted mean annual ${ }^{18} \mathrm{O}$ content in the precipitation and the mean annual near-surface air temperature can be found. This supports the opinion that the observed scatter of annual ${ }^{18} \mathrm{O}$ contents within the relatively short observation period of a few years is not due to temperature changes alone.

3.4. The decrease of the ${ }^{18} \mathrm{O}$ content with distance from the ice edge

Along the traverse on the Filchner-Ronne ice shelves (Fig.2) there is a notable decrease in the mean annual ${ }^{18} \mathrm{O}$ content from Filchner station (T140) to traverse point T340 (Fig.9). This trend is to be expected from the lower mean annual near-surface air temperature at traverse point $\mathrm{T} 340$, and from the greater distance from the ice edge. The shift in the mean ${ }^{18} \mathrm{O}$ value from $-24.3 \%$ at Filchner station to $-28.3 \%$ at traverse point T340 amounts to $4.0 \%$. Thus, according to the present results, a gradient in the ${ }^{18} \mathrm{O}$ content of $1.0 \%$ per $50 \mathrm{~km}$ is observed on the Filchner-Ronne ice shelves. On Ross Ice Shelf a smaller gradient of $1 \%$ per $65 \mathrm{~km}$ was found (Clausen and others 1979). Figure 9 also shows that the $\delta^{18} \mathrm{O}$ differences between the corresponding winter minima of the two snow pits are smaller $(3.5 \pm 0.5 \%$ ) than those of the summer maxima $(5.1 \pm 3.0 \%$ \% . Possible explanations may be the lower accumulation rate at traverse point $\mathrm{T} 340$, and the seasonal fluctuation in the ice cover of the Weddell Sea.

Using Equation (1) and the mean annual near-surface air temperature, represented by the firn temperature at $10 \mathrm{~m}$ depth, a mean ${ }^{18} \mathrm{O}$ content may be calculated. There is a good agreement with the measured values (Table I) for traverse point T340, but not for Filchner station. However, the difference in mean ${ }^{18} \mathrm{O}$ content between these two points on the Filchner-Ronne ice shelves is possibly explainable by applying the simple Rayleigh distillation model with all assumptions included.

$$
\frac{(\delta+1000)_{\mathrm{T} 340}}{(\delta+1000)_{\mathrm{T} 140}} \approx \mathrm{f}(\alpha-1) .
$$

Here $\alpha$ is the equilibrium isotopic fractionation 
6 $18-0[\% \cdot]$

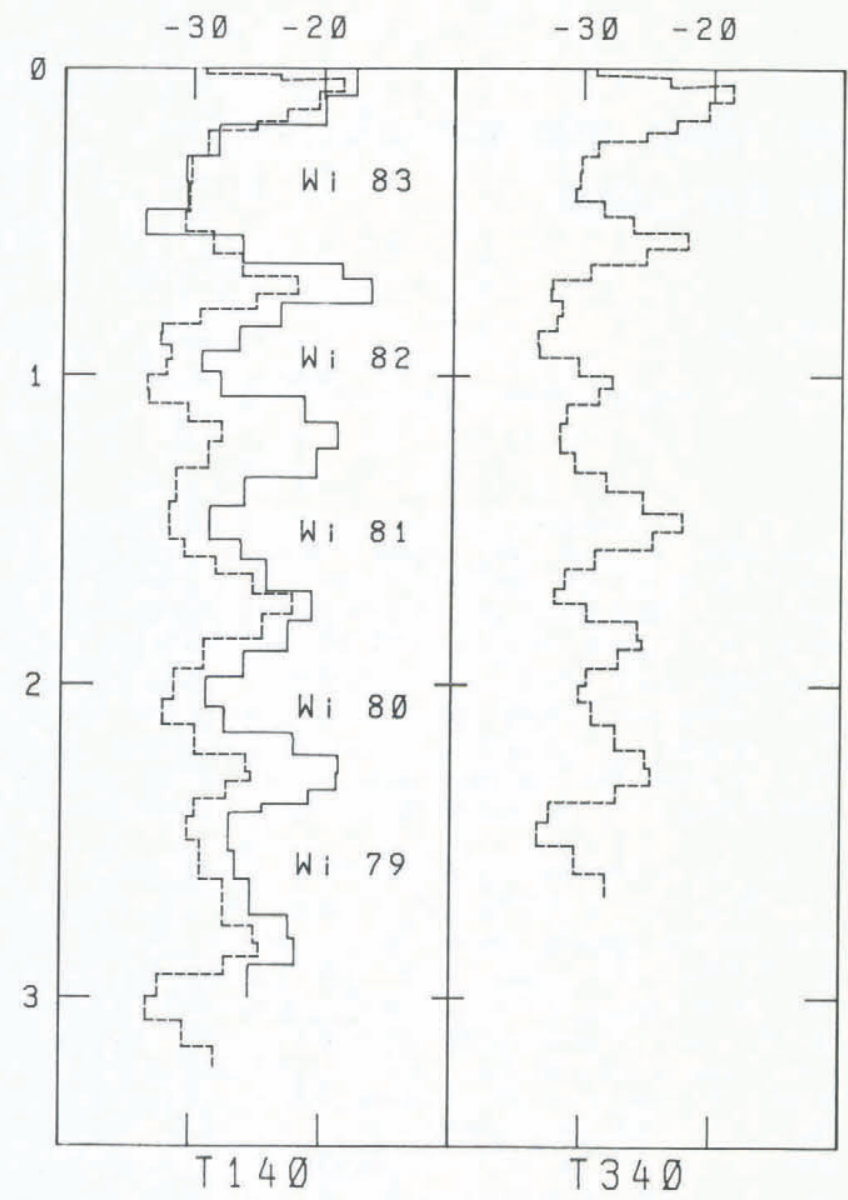

depth $[m]$

Fig. 9. Profiles of ${ }^{18} \mathrm{O}$ content in snow pits located near Filchner station (T140), and at traverse point $\mathrm{T} 340$, both dug in 1984 (Fig.2). The depth axis of the T340 curve (right) has been deformed and the ${ }^{18} \mathrm{O}$ profile superimposed on the T140 profile (left).

factor for the phase transition from vapour to solid, and $f$ is the fraction of vapour remaining in the cloud as condensation proceeds. It is assumed that the temperature of condensation is approximately equal to the mean near-surface air temperature. Finally, the remaining fraction may be given by the ratio of the vapour pressures corresponding to the near-surface air temperatures of the two sites (see e.g. Fig.4).

With $\alpha=1.0197$ (Majoube 1971) and $f=0.68$, a decrease in the ${ }^{18} \mathrm{O}$ content of $3.6 \%$ results from Equation (2), which is close to the measured value.

\section{ACKNOWLEDGEMENTS}

Gratitude must be expressed to the Alfred-Wegener-Institut für Polarforschung, Bremerhaven for logistic support, and to the Deutsche Forschungsgemeinschaft for financial support.

\section{REFERENCES}

Clausen H B, Dansgaard W, Nielsen J O, Clough J W 1979 Surface accumulation on Ross Ice Shelf. Antarctic Journal of the United States 14(5): 68-72

IAEA 1981 Statistical treatment of environmental isotope data in precipitation. Vienna, International Atomic Energy Agency (Technical Report Series 206)

IAEA 1983 Environmental data No 7. World survey of isotope concentration in precipitation (1976-1979). Vienna, International Atomic Energy Agency (Technical Report Series 226)
Lorius C 1983 Antarctica: survey of near-surface mean isotopic values. In Robin $\mathrm{G}$ de $\mathrm{Q}(e d)$ The climatic record in polar ice sheets. Cambridge etc, Cambridge University Press: $52-56$

Lorius C, Merlivat L 1977 Distribution of mean surface stable isotope values in East Antarctica: observed changes with depth in the coastal area. International Association of Hydrological Sciences Publication 118 (General Assembly of Grenoble 1975 - Isotopes and Impurities in Snow and Ice): $127-137$

Majoube M 1971 Fractionnement en ${ }^{18} \mathrm{O}$ entre la glace et la vapeur d'eau. Journal de Chimie Physique et de Physico-Chimie Biologique 68: 625-636

Reinwarth O 1981 Glazialmeteorologische Arbeiten auf dem Filchner-Ronne-Schelfeis während der Standorterkundungsexpedition 1979/80. Polarforschung 51(1): 61-75

Reinwarth O, Rauert W, Stichler W, Moser H 1982 Preliminary investigations on accumulation at the Filchner/Ronne ice shelves and Atka Bay. Annals of Glaciology 3: 274-278

Robin G de Q 1977 Ice cores and climatic change, Philosophical Transactions of the Royal Society of London Ser B 280(972): 143-168

Robin G de Q, Johnsen S J 1983 Atmospheric processes. In Robin $\mathrm{G}$ de $\mathrm{Q}$ (ed) The climatic record in polar ice sheets. Cambridge etc, Cambridge University Press: 47-52 